University of South Florida

DIGITAL COMMONS

Digital Commons @ University of

@ UNIVERSITY OF SOUTH FLORIDA

South Florida

\title{
Analysis of Florida Department of Transportation Transit Corridor Program/Projects: Technical Memorandum \#3 - Recommendations
}

CUTR

Follow this and additional works at: https://digitalcommons.usf.edu/cutr_nctr

\section{Scholar Commons Citation}

CUTR, "Analysis of Florida Department of Transportation Transit Corridor Program/Projects: Technical Memorandum \#3 - Recommendations" (2001). Research Reports. 6.

https://digitalcommons.usf.edu/cutr_nctr/6

This Technical Report is brought to you for free and open access by the National Center for Transit Research (NCTR) Archive (2000-2020) at Digital Commons @ University of South Florida. It has been accepted for inclusion in Research Reports by an authorized administrator of Digital Commons @ University of South Florida. For more information, please contact digitalcommons@usf.edu. 


\title{
ANALYSIS OF FLORIDA DEPARTMENT OF TRANSPORTATION TRANSIT CORRIDOR PROGRAM/PROJECTS
}

\author{
Technical Memorandum Number Three \\ General Recommendations
}

Prepared for

Florida Department of Transportation

Prepared by

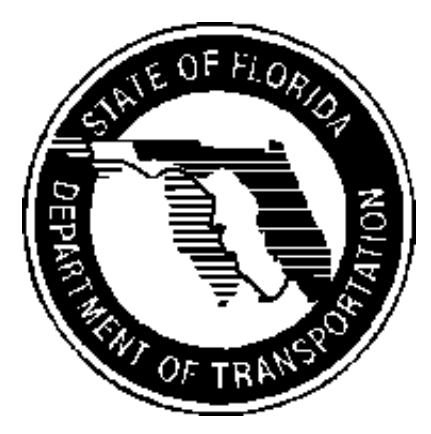
Center for Urban Transportation Research College of Engineering University of South Florida Tampa, Florida

March 2001

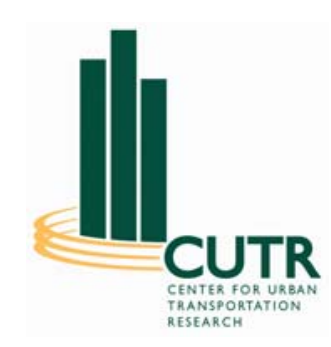




\section{TRANSIT CORRIDOR PROGRAM CONCLUSIONS/RECOMMENDATIONS}

Based on the review of project summaries, surveys of program recipients and FDOT district offices, and discussions with FDOT Central and District Offices, CUTR has drawn the following conclusions and recommendations regarding the Transit Corridor Program procedure and monitoring.

\section{Overall Program Issues}

1. Definition of eligible projects under the Transit Corridor Program

The current definition of eligible transit corridor projects as outlined in the definition section of the Transit Corridor Program Procedure (Topic \#725-030-003-e) includes "a project identified in a Transit Development Plan, Congestion Management System Plan, or other formal study undertaken by a public agency designed to relieve congestion and improve capacity within an identified corridor, by increasing people carrying capacity through the use and facilitated movement of high occupancy conveyances." CUTR has concluded that all 27 Joint Participation Agreements (JPA's) executed for the report period followed the criteria for the current definition. Surveys of recipients did not indicate that any changes to eligible projects were desired.

RECOMMENDATION: No change to the definition.

2. Project Management and Implementation

This section identifies the specific project management and responsibilities of both FDOT Central Office and District Office personnel who manage the Transit Corridor Program.

Section 2. $(H)$, provides that districts report to the Central Office "periodically," no less than biennially, on the success and failure of the program and asks for recommendations for change, if any.

CUTR suggests that FDOT Central Office staff be informed of the relative success/failure of projects on an annual basis as justification for their continuance. This report should be provided prior to any work program development activities related to the project and should contain a listing of all goals and objectives with corresponding data suggesting the project either exceeded, met, or did not meet those goals and 
objectives. This should assist Central Office staff with the annual project reviews and corresponding targeting of funds for the projects.

RECOMMENDATION: Language in $2 . \mathrm{H}$ should be revised to read: Districts shall report to Central Office on an annual basis to provide documentation supporting the relative success of a project in meeting the goals, objectives, and milestones established for the period. This shall be done prior to work program development activities for the continuation of the project.

\section{Funding and Eligible Costs}

The first priority for funding under the Transit Corridor Program is to existing projects meeting their adopted goals and objectives. Next, remaining funds are to be allocated to the districts by formula. The districts have the opportunity to program up to 100 percent of the cost for transit corridor projects.

RECOMMENDATION: Due to the limited funding in the program and based on comments received that suggest there are not enough funds available to adequately fund existing projects or new projects, it is CUTR's recommendation that the Department consider distribution of funds and continuation of projects based on the local participation provided to that project. In other words new projects that have garnered a great deal of local funding support and existing programs receiving local support and meeting the goals, objectives, and milestones established should be considered for funding prior to new projects requesting 100 percent state funds or existing projects that are receiving 100 percent state funds with little or no local funding made available.

\section{Capital Acquisition and Management}

Section 2.1.2 states that vehicles that are no longer required for a particular project be returned to the State Bus Fleet for reallocation or disposal.

RECOMMENDATION: CUTR recommends revising the current procedure to allow the Department to release the title of vehicles purchased through the program to the public agencies who have control of those vehicles, as long as they are being used to provide public transportation services. Or, for newer vehicles, allow agencies to purchase vehicles from the Department for the balance of the depreciated value of the vehicle. 


\section{Project Implementation and Monitoring}

The Technical Advisory Group (TAG)

Section 3.1 provides that a Technical Advisory Group (TAG) be established "upon the approval of a transit corridor project." Section 3.4 establishes that goals, objectives, and milestones and decision points for a transit corridor project be defined by the grantee, adding that "input may be received from the TAG and Central Office." This section is inconsistent with the definition of the TAG which states: "This group establishes goals and objectives for the project, evaluates the project's successes and/or failures, and recommends further actions. Recognizing the importance of allowing the grantees to define the goals, objectives, and milestones of their projects, CUTR's recommendation would be as follows:

RECOMMENDATION: CUTR recommends that the language in the definition be changed to reflect the TAG's role in providing input into the process of establishing goals, objectives, milestones, and decision points for the project. While this lessens the TAG's authority over each of the projects in establishing benchmarks for performance it still enables them to accurately and effectively evaluate each project. If at the end of a review period a project has either not met or has exceeded the objectives and milestones established, the TAG should be involved in determining whether or not the objectives and milestones established should be revisited and/or adjusted. The grant recipient should then follow the guidance provided by the TAG.

Goals, Objectives, Milestones

Section 3.4 provides that all corridor projects have clearly defined goals and objectives. Milestones must also be established by which progress is evaluated. Goals and objectives with corresponding milestones were not readily available in all of the project files. In addition, in cases where goals, objectives and/or milestones had been revised, these changes were not consistently identified and justified.

RECOMMENDATION: This is an area that should continually be reviewed and monitored. If goals, objectives and milestones are not clearly delineated in a project file, how will new FDOT district staff, the TAG, or others confirm the success/failure of a project? Again, the annual reports provided to Central Office should reveal those projects where these are missing or are inconsistent with previously established goals, objectives, and milestones. Goals, objectives, and milestones should clearly be 
established and reviewed by the districts when making the case for continued funding.

As stated previously, an accurate and effective annual evaluation of each project should be completed by the TAG. If at the end of a review period a project has either not met or has exceeded the objectives and milestones established, the TAG should be involved in determining whether or not the objectives and milestones established should be revisited and/or adjusted. The grant recipient should then follow the guidance provided by the TAG.

\section{Progress Reports}

Section 3.5 of the procedure provides that written progress reports be established as part of the Joint Participation Agreement and submitted no less than quarterly. In review of the transit corridor projects, progress report submittals ranged from quarterly to annually and were provided in a plethora of formats from very sketchy to lengthy. The absence of consistent progress reporting has made the evaluation of the program a difficult task.

RECOMMENDATION: CUTR's recommendation is that the district transit staff be given the opportunity to require progress reports at greater intervals, especially for long-term ongoing, successful projects. For some projects, it may only be necessary to require annual reports with updates periodically when changes are made or if sufficient activity related to the project has occurred. In addition, for those projects that are limited in their scope (example: marketing campaign or surveys), it is recommended that only a final report be required.

In order to address the diversity in the reports submitted, CUTR recommends that all agencies report the same core information, both quarterly performance (if reports required on a quarterly basis) and annual performance (which, if only annual reports are required, would provide cumulative monthly or quarterly statistics). Each report should contain the WPI or FPN number; name of the project as it appears on the joint participation agreement; brief project summary; goals for the project (and if there have been any changes to the goals, objectives or milestones during the period); performance measures, including, but not limited to: ridership, revenue, and expenses; any changes to the route or schedule during the period; and any significant successes or activities that occurred during the reporting period. Any requested changes to a projects' scope, time or budget should also be included in the progress report. 
We are not suggesting a standard format or "boilerplate" for the report, but are suggesting that minimum reporting criteria are met.

\section{FDOT DISTRICT CONCLUSIONS/ RECOMMENDATIONS FOR THE TRANSIT CORRIDOR PROGRAM}

The following section identifies suggested changes to the Transit Corridor Program made by FDOT district staff.

C A minimum of three (3) years of funding in the tentative work program each year. (2 responses)

CUTR Response: This is a good suggestion. At a minimum, districts should have the ability to program in the second and third year of the Work Program, the amount of Transit Corridor funds they are currently receiving. This may also lend itself to the establishment of multi-year JPAs for transit corridor projects. This could result in a reduction of work load for district staff.

C The possibility of some minimum success standards to be used as a starting point for establishing project goals.

CUTR Response: Absolutely agree. However, establishing statewide minimum standards may be too exhausting. A project's success relative to the standards established locally is strictly subjective. Operating environments, external influences, etc. all effect an agency's ability to implement corridor projects. Locally developed standards (which in this case I would establish as goals, objectives, and milestones) should be just that, local.

There certainly are valid arguments for reviewing projects that consistently are either exceeding or failing to meet the goals and objectives established. It may be that the objectives and milestones established for the project were not ambitious enough or were too ambitious. As provided above, if at the end of a review period a project has either not met or has exceeded the objectives and milestones established, the TAG should be involved in determining whether or not the objectives and milestones established should be revisited and/or adjusted. The grant recipient should then follow the guidance provided by the TAG.

C A requirement to include public involvement in any/all project proposals. 
CUTR Response: In previous technical memoranda the importance of public involvement throughout the process was noted time and again. CUTR would concur with this recommendation to provide for public involvement in the development stage. This could include a locally developed process for gaining public input through the use of the MPO's various advisory committees, the transit agency's advisory or citizens committees, or advocacy groups. Any process/procedure that is developed should be a part of the contract file at the district FDOT office and should be provided as an attachment to the first progress supported for the project. We would not suggest that this public involvement occur through a "public hearing" or other formalized process.

C Make all new projects, and those that are successful and being continued with state funding, multi-year!

CUTR Response: CUTR concurs with this recommendation. The use of multi-year joint participation agreements should result in fewer FDOT district staff hours spent in the contract renewal process.

C Although there is no time limit on this program, maybe we should have a maximum of ten (10) years even if the project is meeting its goals, particularly with a decrease in funds the last few years of the program.

CUTR Response: While in general this suggestion makes sense, especially for those ongoing projects that may be meeting the goals established yet are not as successful as the FDOT district would have anticipated, it may be too limiting. Projects that are extremely or "very successful," as noted in prior technical memoranda, may continue for many years. It would be unfortunate to end the project because of a procedural requirement. CUTR would suggest maintaining the flexibility that exists in the current procedure.

C I would like to see the Transit Corridor Program be less labor intensive and more user friendly. Eliminate all the "transit corridor constraint"/TAG requirements, etc. It could be used for a sub-area or county. I feel several programs could be mixed with this one so you could blend funding to a better use. Commuter Assistance, carpool/vanpool assistance, park \& ride facilities, and Service Development activities are all included in the eligible costs and could eliminate the need for separate funding sources and procedural requirements. 
CUTR Response: We agree that the administration of the Transit Corridor Program should be less labor intensive and more user friendly. The use of multiyear joint participation agreements should result in fewer FDOT district staff' hours spent in the contract renewal process. In addition, with minimum criteria established for progress reports and fewer reports required per year, this should result in fewer FDOT and agency staff hours devoted to progress report development and review.

CUTR recommends that the FDOT NOT consider combining the Transit Corridor Program with any other FDOT funding program. It is critical to maintain the separate identity and integrity of this program. The Transit Corridor Program has a very specific goal, to provide funding to public agencies to undertake projects designed to relieve congestion and improve capacity within an identified constrained corridor. It is important to maintain the autonomy of the program to ensure the continued success of the program and allow for effective comprehensive reviews of each project.

C State funding only pays for a small portion of the actual cost of providing the service. Suggest more funding.

CUTR's Response: Additional funding would certainly be an acceptable program enhancement for agencies participating in this program and those that would participate if only there were enough funds available in the program. CUTR is very active in the development of Transit Development Plans for many of Florida's transit agencies. There are many projects that transit agencies would like to undertake if only they had access to additional funds. Many of these projects are directly related to the relief of congestion along major corridors, and include improvements such as express bus service or Bus Rapid Transit (BRT), circulators that feed into mainline routes, advance public transportation systems (APTS), etc.

While in the surveys documented in Technical Memorandum \#2, eleven of the thirteen properties indicated that they received adequate funding. However, it is important to note that the only agencies surveyed were those who were successful in applying for and receiving transit corridor funds.

C Only annual reports should be required for Transit Corridor projects that are longterm, ongoing projects. 
CUTR's Response: Agree, please see comments above.

C Dedicated district allocations.

CUTR Response: This is a good suggestion. A minimum of three (3) years of funding should be identified in the tentative work program each year, as suggested above. At a minimum, districts should have the ability to program in the second and third year of the Work Program, the amount of Transit Corridor funds they are currently receiving. This may also lend itself to the establishment of multi-year JPAs for transit corridor projects. This could result in a reduction of work load for district staff.

C Combine this program with the Service Development Program.

CUTR's Response: We respectfully disagree. As provided above, CUTR recommends that the FDOT NOT consider combining the Transit Corridor Program with any other FDOT funding program. It is critical to maintain the separate identity and integrity of this program. The Transit Corridor Program has a very specific goal,

to provide funding to public agencies to undertake projects designed to relieve congestion and improve capacity within an identified constrained corridor. It is important to maintain the autonomy of the program to ensure the continued success of the program and allow for effective comprehensive reviews of each project.

C We don't have enough funds to provide the additional services that are needed. We need additional capital and operating funds.

CUTR's Response: We agree that additional funds are needed for the program. Please see the comments made above.

C "I am always interested in reducing reporting requirements."

CUTR's Response: Please see comments above related to reporting requirements. 